\title{
Kinetics of the formation of the factor $X$ activating enzyme of the blood coagulation system
}

Citation for published version (APA):

Varadi, K., \& Hemker, H. C. (1976). Kinetics of the formation of the factor X activating enzyme of the blood coagulation system. Thrombosis Research, 8(3), 303-317. https://doi.org/10.1016/0049-3848(76)90024-4

Document status and date:

Published: 01/03/1976

DOI:

10.1016/0049-3848(76)90024-4

Document Version:

Publisher's PDF, also known as Version of record

\section{Please check the document version of this publication:}

- A submitted manuscript is the version of the article upon submission and before peer-review. There can be important differences between the submitted version and the official published version of record.

People interested in the research are advised to contact the author for the final version of the publication, or visit the DOI to the publisher's website.

- The final author version and the galley proof are versions of the publication after peer review.

- The final published version features the final layout of the paper including the volume, issue and page numbers.

Link to publication

\footnotetext{
General rights rights.

- You may freely distribute the URL identifying the publication in the public portal. please follow below link for the End User Agreement:

www.umlib.nl/taverne-license

Take down policy

If you believe that this document breaches copyright please contact us at:

repository@maastrichtuniversity.nl

providing details and we will investigate your claim.
}

Copyright and moral rights for the publications made accessible in the public portal are retained by the authors and/or other copyright owners and it is a condition of accessing publications that users recognise and abide by the legal requirements associated with these

- Users may download and print one copy of any publication from the public portal for the purpose of private study or research.

- You may not further distribute the material or use it for any profit-making activity or commercial gain

If the publication is distributed under the terms of Article $25 \mathrm{fa}$ of the Dutch Copyright Act, indicated by the "Taverne" license above, 
THROMBOSIS RESEARCH

Printed in the United States
Vo1. 8, pp. 303-317, 1976

Pergamon Press, Inc.

KINETICS OF THE FORMATION OF THE FACTOR X ACTIVATING

ENZYME OF THE BLOOD COAGULATION SYSTEM

K.Varadi ${ }^{*}$, H.C. Hemker

Department of Biochemistry, State University Limburg,

Maastricht, The Netherlands.

(Received 20.11.1975; in revised form 15.1.1976.

Accepted by Editor L. Vroman)

ABSTRACT

The generation of factor X converting activity ("tenase") from factor IX factor VIII and inosithin has been studied using > 95\% pure preparations of the coagulation factors.

It was found that:

a. The three reactants mentioned above and $\mathrm{Ca}^{++}$ions are necessary to obtain full "tenase" activity. Factor IX has some "tenase" activity of its own.

b. The reactants were functional in the form in which they were added.

c. The time course of the development of the tenase activity and the dependence of "tenase" concentration on the concentration of the reactants are compatible with the reaction scheme:

$\mathrm{IX}_{\mathrm{a}}+\mathrm{Ca}^{++}+$ph.lip. $\rightleftarrows \quad \mathrm{IX}_{\mathrm{a}}-\mathrm{Ca}-$ ph.lip.

VIII +ph.lip. $\longrightarrow$ VIII - ph.lip.

$I_{\mathrm{a}}-\mathrm{Ca}-\mathrm{ph.7ip.+VIII} \longrightarrow$ tenase

VIII - ph. lip. $+\mathrm{Ca}^{++}+\mathrm{IX}_{\mathrm{a}} \rightleftarrows$ tenase.

d. High phospholipid concentrations are inhibitory. At inhibitory phospholipid concentrations "tenase" forms more slowly than at non-inhibitory concentrations. Under these conditions there is a lag-phase in the conversion of factor $x$. This is suggestive of formation of tenase and of the tenase-factor $X$ complex by lateral movement of molecules adsorbed at the phospholipid-water interphase.

\section{INTRODUCTION}

The enzyme that converts prothrombin into thrombin in the normal blood

\footnotetext{
* Present address: Laboratory of Blood Coagulation,

National Institute of Hematology and Blood Transfusion,

Budapest, Hungary. 
coagulation process of man, cow and other mammals has been shown to consist of two proteins, factor $X_{a}$ and factor $V$, adsorbed next to each other at a phospholipid-water interphase (1). Factor $x_{a}$ is a serine protease that contains the active site that brings about the splitting of the peptide bonds in prothrombin. Factor $V$ is a protein without enzymatic properties that contains binding sites for factor II (2) and that presumably ensures a favourable juxtaposition of the active site of factor $x_{a}$ and the vulnerable sites in prothrombin. The evidence in favour of this model is

1. For generating prothrombinase of optimal activity the simultaneous presence of factor $x_{a}, V$, and phospholipid is necessary $(3,4)$.

2. The factors $X_{a}$ and $V$ bind to phospholipids and the prothrombinase activity is lipid bound $(5-8)$.

3. The kinetics of the formation of prothrombinase activity is compatible with the reaction scheme:

$\mathrm{X}_{\mathrm{a}}+\mathrm{Ca}^{++}+$ph. lip.

$\checkmark+$ ph. lip.

$X_{a}-C a-p h .7 i p .+V$

$\mathrm{V}-$ ph. $1 \mathrm{ip.}+\mathrm{Ca}^{++}+\mathrm{X}_{\mathrm{a}}$

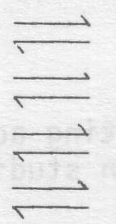

$X_{a}-C a-p h$. lip.

$\checkmark \quad-p h$. lip.

prothrombinase

prothrombinase (9).

It has been postulated that the enzyme that converts factor $X$ into factor $x_{a}$ (tenase) in the so-called "intrinsic pathway" of blood coagulation is a complex analogous to prothrombinase consisting of the factors IX $\mathrm{A}_{\mathrm{a}}$ and VIII adsorbed at a phospholipid-water interphase. The experimental evidence is of the kind mentioned sub 1 and 2 (10-15). This article describes kinetic experiments with purified coagulation factors designed to verify this hypothesis.

\section{MATERIALS AND METHODS}

Pooled platelet free plasma of 50 healthy male volunteers prepared as in ref. 16, and stored at $-70^{\circ} \mathrm{C}$ was used as standard normal plasma. Michaelis buffer was used as a diluent unless indicated otherwise. Clotting factor assays: one unit of coagulation factor was defined as the amount present in $1 \mathrm{ml}$ of standard human plasma. Factor $X$ was measured in a one-stage assay as described by Hemker et al.(16). Factor $x_{a}$ was measured in a one-stage assay analogous to the factor $X$ assay using plasma, made deficient in factors $X$ and VII by Seitz filtration in combination with phospholipid suspension $(10 \mu \mathrm{g} / \mathrm{ml})$, prepared as indicated below, in 1 ieu of thromboplastin.

A reference curve for factor $X_{a}$ was made by assaying serial dilutions 
of a preparation containing $10 \mathrm{U} / \mathrm{ml}$ of factor $x_{a}$. This preparation was obtained by complete activation of a solution containing $10 \mathrm{U} / \mathrm{ml}$ of factor $X$ by means of adding $2 \mu \mathrm{g} / \mathrm{ml}$ of Russell's Viper venom and $10 \mathrm{mM} \mathrm{Ca}^{++}(17)$. Factors VIII and IX were assessed in a one-stage assay as described by Thomson (18) using congenitally deficient plasmas $(<0.01 \mathrm{U} / \mathrm{ml}$ of the deficient factor) as a reagent. Reference curves were obtained by assaying dilutions of standard normal plasma. Factor IX was assessed as factor IX, but care was taken not to activate the sample and therefore no kaolin was added and plastic tubes and pipettes were used throughout.

Purified clotting factors: factor IX $X_{a}$ was prepared from human serum, as described by Varadi and Elödi (19). The specific activity was $15 \mathrm{U} / \mathrm{mg}$, and the preparation was free from other clotting factors (II, V, VII, VIII, $I X, X, X I, X I I)$ and showed only traces of contaminating proteins on polyacrylamide gel electrophoresis.

Factor VIII was prepared from human plasma (20). It was kindly supplied by Dr.v.Mourik in the form of an ammonium sulphate precipitation. The suspension contained $11 \mathrm{U} / \mathrm{ml}$ of factor VIII with a specific activity of $7 \mathrm{U} / \mathrm{mg}$. Before use a part of this suspension was redissolved in $0.05 \mathrm{M}$ Tris- $\mathrm{HCl}$ buffer $\mathrm{pH} 7.2$. The preparation did not contain measurable activities of other coagulation factors.

Factor $X$ prepared from bovine plasma according to Fujikawa (7) was a gift of Drs.M.J.Lindhout. The specific activity of the preparation was $65 \mathrm{U} / \mathrm{mg}$. Thrombin (bovine) was obtained commercially from S.A. F. HoffmannLa Roche (Basel, Switzerland). Contact product was prepared according to Nossel (21). Phospholipid suspension: a $50 \mathrm{mg} / \mathrm{ml}$ stock suspension of inosithin (Associated Concentrates, USA) was made by homogenezing the material in a glass-glass Potter Elvehjem homogenizer in $0.05 \mathrm{M} \mathrm{Tris-HCl}$ buffer $\mathrm{pH} 7.2$. The stock suspension was stored in small portions at $-20^{\circ} \mathrm{C}$ and diluted before use to the desired concentrations: all materials were never frozen and thawed more than once.

\section{EXPERIMENTAL}

In all experiments factor VIII, factor IX ${ }_{a}$, inosithin suspension, and $\mathrm{Ca}^{++}$were added together in a first incubation mixture. After a given incubation time factor $X$ was added to a final concentration of $0.65 \mathrm{U} / \mathrm{ml}\left(14.10^{-11_{M}}\right.$ ); this made the second incubation mixture. Samples were taken from this second incubation mixture and diluted 10-fold in icecold Michael is buffer and tested for factor $x_{a}$ activity. From the rate of generation of factor $x_{a}$ 
the factor X converting activity ("tenase") was estimated. One unit of "tenase" was arbitrarily defined as the amount that formed $1 \mathrm{mU}$ of factor $x_{a}$ per minute.

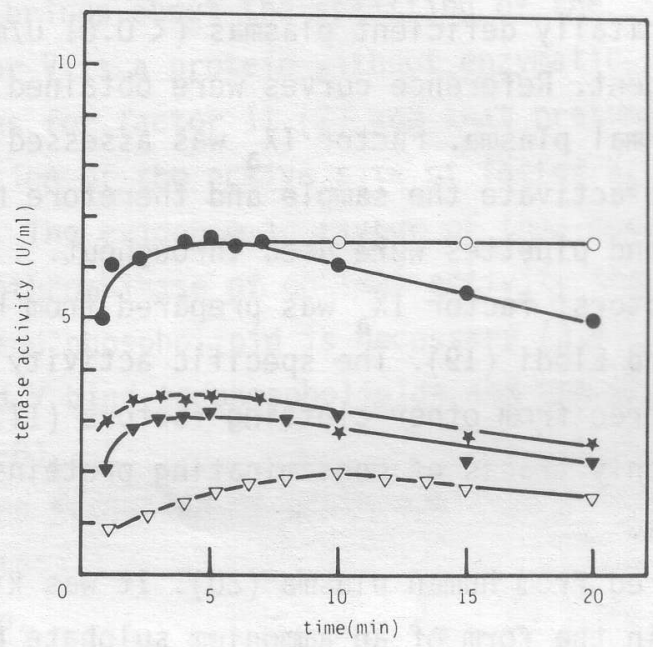

FIG.1.

Time course of tenase activity. At zero time to a mixture of factor IX and factor VIII inosithin and $\mathrm{Ca}^{++}(20 \mathrm{mM})$ were added. Incubation temperature $37^{\circ} \mathrm{C}$.

- - factor IX $0.8 \mathrm{U} / \mathrm{ml}$, factor VIII $0.4 \mathrm{U} / \mathrm{ml}$, inosithin $10 \mu \mathrm{g} / \mathrm{ml}$

0 - o the same cooled to $2^{\circ} \mathrm{C}$ at $5 \mathrm{~min}$

* - * factor IX $0.8 \mathrm{U} / \mathrm{ml}$, factor VIII $0.1 \mathrm{U} / \mathrm{ml}$, inosithin $10 \mu \mathrm{g} / \mathrm{m}]$

$\nabla$ factor IXa $0.1 \mathrm{U} / \mathrm{ml}$, factor VIII $0.4 \mathrm{U} / \mathrm{ml}$, inosithin $10 \mu \mathrm{g} / \mathrm{ml}$

$\nabla-\nabla$ factor $I_{a}^{a} 0.8 \mathrm{U} / \mathrm{ml}$, factor VIII $0.4 \mathrm{U} / \mathrm{ml}$, inosithin $40 \mu \mathrm{g} / \mathrm{ml}$.

Full tenase activity developed in the first incubation mixture when factors VIII and $I_{a}$ were present together with inosithin and $\mathrm{Ca}^{++}$(Table I).

TABLE I

FORMATION OF FACTOR $X$ ACTIVATING ENZYME

Reactants

factor IX

factor VIII

inosithin

$\mathrm{Ca}^{++}$

Xase activity $(\mathrm{U} / \mathrm{ml})$
Final Concentration

$0.8 \mathrm{U} / \mathrm{ml}$

$0.4 \mathrm{U} / \mathrm{ml}$

$10 \mu \mathrm{g} / \mathrm{ml}$

$20 \mathrm{mM}$

20

$\begin{array}{llllll}7 & 0.6 & 0.5 & 0.3 & 0.1 & 0.1\end{array}$

The reactants were added to $0.05 \mathrm{M}$ Tris- $\mathrm{HCl}$ buffer $\mathrm{pH} 7.2$ to the final concentrations indicated. The first incubation was 5 min at $37^{\circ} \mathrm{C}$. 
Factor $\mathrm{IX}_{\mathrm{a}}$ together with $\mathrm{Ca}^{++}$had an activity of less than $10 \%$ of that of the complete mixture. In the complete mixture $90 \%$ of the activity appeared within 1 minute when non-inhibiting concentrations of phospholipid were present. With high phospholipid concentrations the generation of tenase activity was slower. After 5-7 minutes the activity in the complete mixture started to decrease. This could be prevented by cooling it to $2^{\circ} \mathrm{C}$ (fig. 1 ).

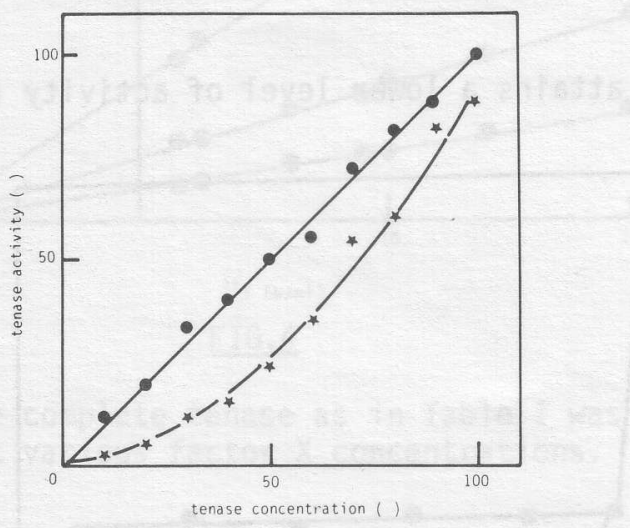

FIG.2

Activity-concentration relationship of a tenase preparation. The $100 \%$ preparation is the complex mixture of Table I kept at ice after 5 min of incubation.

- activity immediately after dilution with ice-cold Michaelis buffer * - * activity after 5 min incubation at $37^{\circ} \mathrm{C}$.

Preincubation of factor VIII and factor IX ${ }_{a}$ did not result in an enhanced activity nor was one of these factors activated by factor $x_{a}$ or thrombin or contact product (Table II).

\section{TABLE II}

EFFECT OF PREINCUBATION OF FACTORS IX ${ }_{\mathrm{a}}$ AND VIII

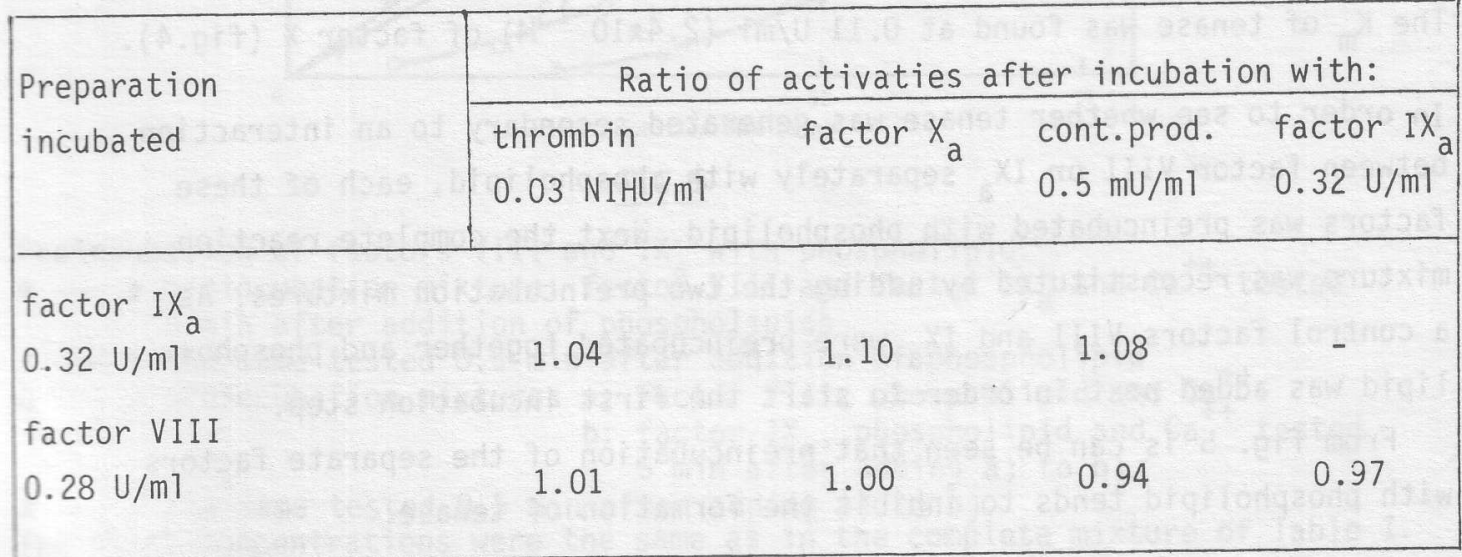


Factor VIII or factor IX were preincubated for 15 min or 5-15 seconds before the complete tenase mixture was prepared. After 1 min the activity of the tenase was tested. The ratio of the activities with long and short preincubation time is shown.

Once tenase had developed the concentration of tenase is proportional to its activity (fig. 2 ).

After dilution tenase attains a lower level of activity (fig. 3 ).

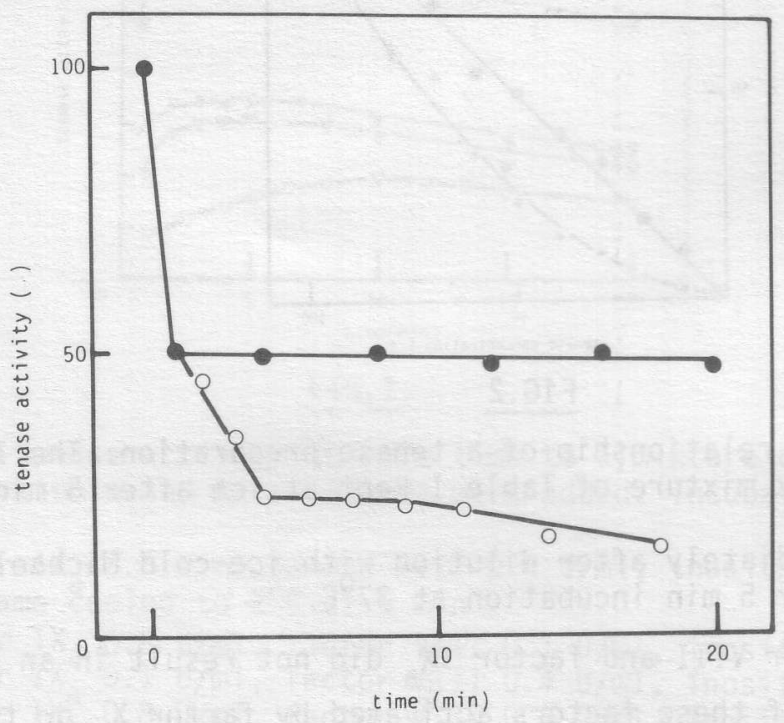

FIG.3 Time course of tenase activity after dilution. The $100 \%$ preparation of
fig. 2 was twice diluted with ice-cold Michaelis buffer and kept at $2{ }^{\circ} \mathrm{C}$ (-) or with buffer at $37^{\circ} \mathrm{C}$ and kept at that temperature $(0-0)$.

The $K_{m}$ of tenase was found at $0.11 \mathrm{U} / \mathrm{ml}\left(2.4 * 10^{-13} \mathrm{M}\right)$ of factor $X$ (fig. 4 ). In order to see whether tenase was generated secondary to an interaction between factor VIII or IX $X_{a}$ separately with phospholipid, each of these factors was preincubated with phospholipid. ivext the complete reaction mixture was reconstituted by adding the two preincubation mixtures. As a control factors VIII and IX were preincubated together and phospholipid was added next in order to start the first incubation step.

From fig. 5 is can be seen that preincubation of the separate factors with phospholipid tends to inhibit the formation of tenase. 


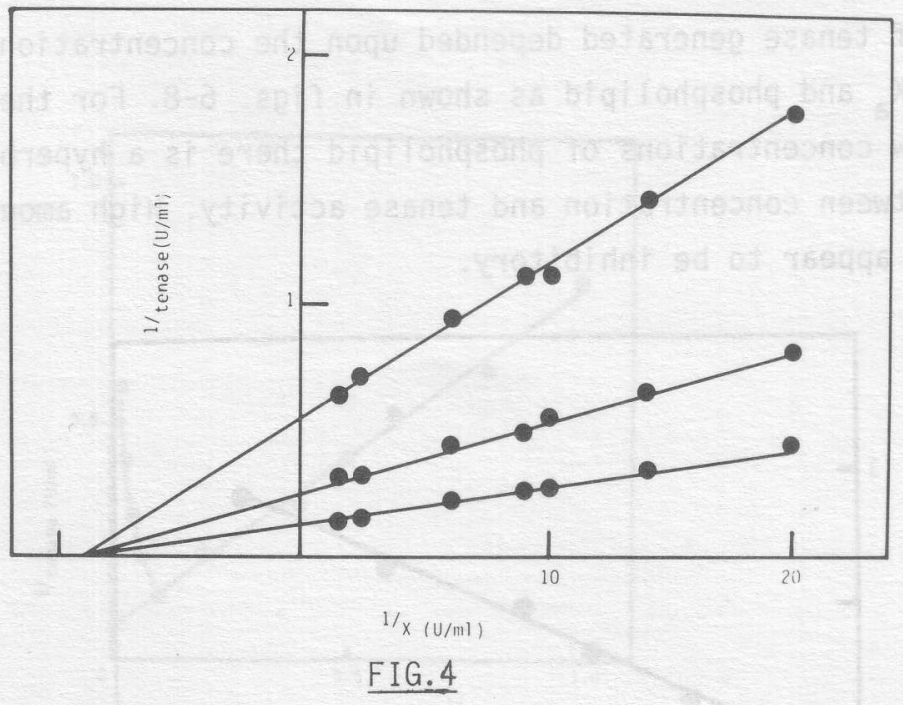

The $K_{m}$ of tenase. The complete tenase as in Table I was diluted $1: 2$ and $1: 4$ and tested at various factor $X$ concentrations.

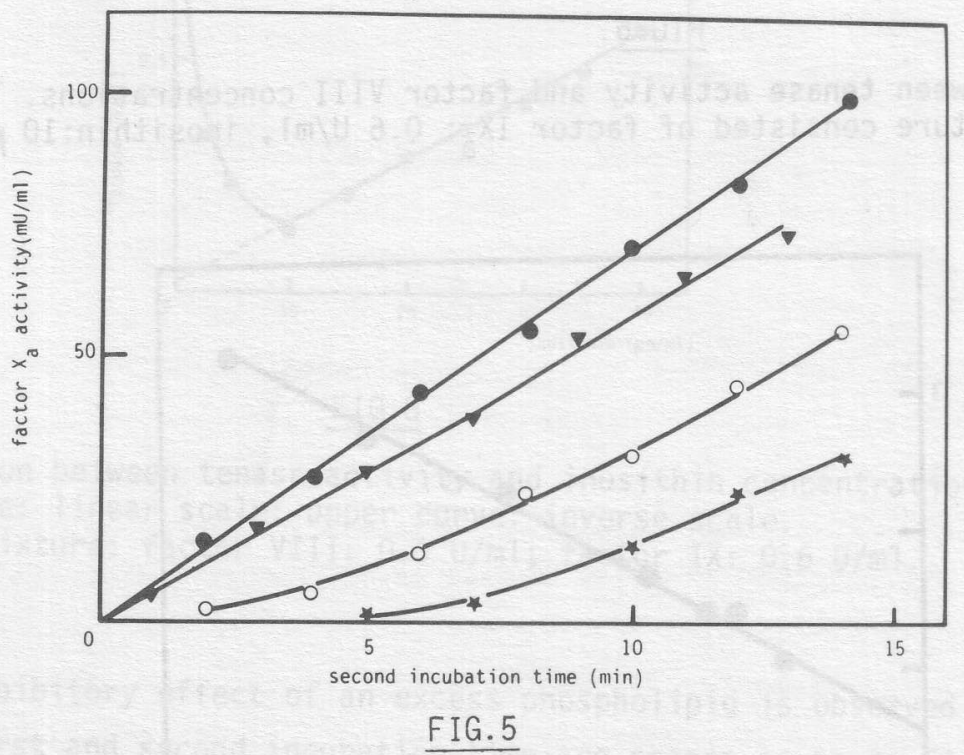

Preincubation of factors VIII and IX with phospholipid.

- preincubation mixture: factor VIII and factor IX ${ }_{a}$ and $\mathrm{Ca}^{++}$tested 5 min after addition of phospholipids

$\checkmark$ the same tested 0.5 min after addition of phospholipid

0 - o preincubation mixtures a: factor VIII, phospholipid and $\mathrm{Ca}^{++}$

b: factor IX, phospholipid and $\mathrm{Ca}^{++}$tested 5 min aftêr adding a) to b)

* - * the same tested 0.5 min after adding a) to b).

The final concentrations were the same as in the complete mixture of Table I. 
The amount of tenase generated depended upon the concentration of factors VIII, IX $a$ and phospholipid as shown in figs. 6-8. For the two proteins and low concentrations of phospholipid there is a hyperbolic relationship between concentration and tenase activity. High amounts of phospholipid appear to be inhibitory.

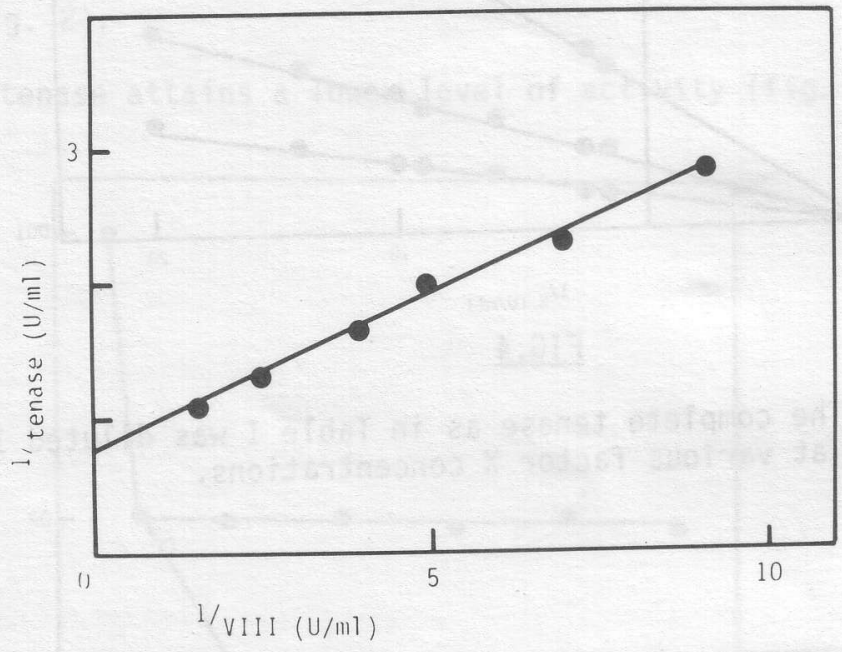

FIG. 6

Rèlation between tenase activity and factor VIII concentrations. The reaction mixture consisted of factor $I_{a}: 0.6 \mathrm{U} / \mathrm{ml}$, inosithin: $10 \mu \mathrm{g} / \mathrm{ml}$ $\mathrm{Ca}^{++}: 20 \mathrm{mM}$.

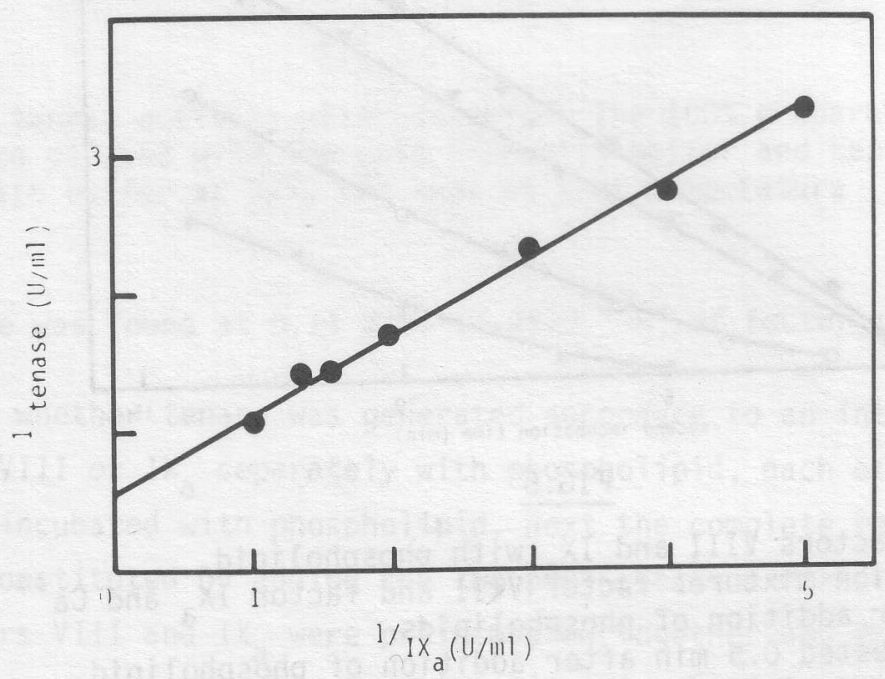

FIG.7

Relation between tenase activity and factor IX concentration. The reaction mixture consisted of factor VIII: $0.3 \mathrm{U} / \mathrm{ml}$, inosithin: $10 \mu \mathrm{g} / \mathrm{ml}, \mathrm{Ca}^{++}: 20 \mathrm{mM}$. 

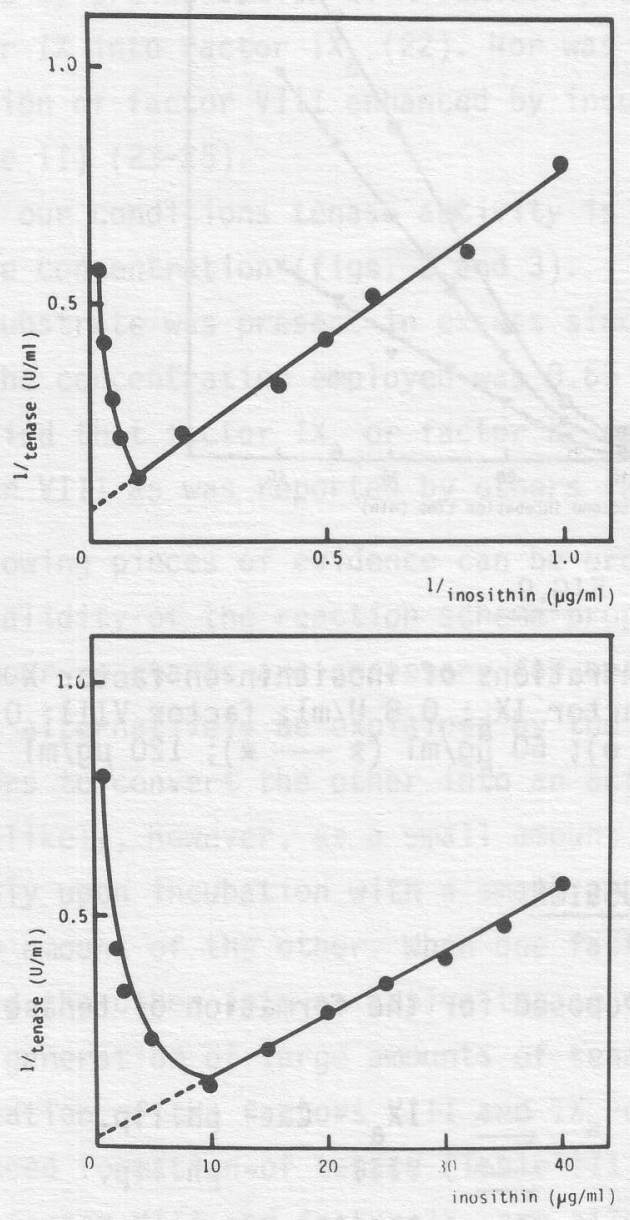

FIG.8

The relation between tenase activity and inosithin concentrations. Lower curve: linear scale: upper curve: inverse scale. Reaction mixture: factor VIII: $0.3 \mathrm{U} / \mathrm{ml}$; factor IX: $0.5 \mathrm{U} / \mathrm{ml}$.

This inhibitory effect of an excess phospholipid is observed even when both first and second incubation time are chosen so as to find a maximum rate of factor $X$ conversion (fig. 8 ). It is independent of two other phenomena also observed at high lipid concentrations:

a. The generation of tenase activity from the complete mixture is slow (fig. 5 ).

b. There is a lag time in factor $x_{a}$ production after the addition of factor X (fig. 9). 


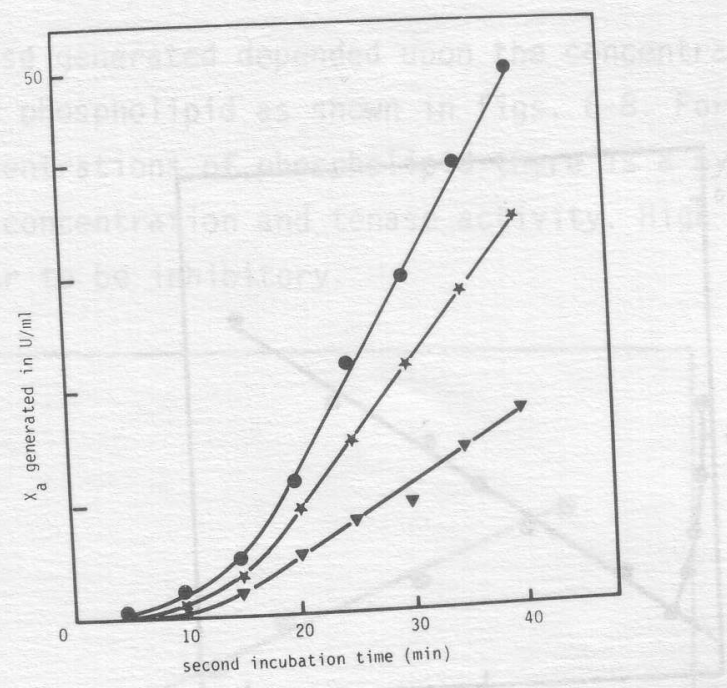

FIG.9

Effect of inhibiting concentrations of inosithin on factor $X$ converaction mixture: factor IX: $0.8 \mathrm{U} / \mathrm{ml}$; factor VIII: $0.4 \mathrm{U} / \mathrm{ml}$; inosithin: $40 \mu \mathrm{g} / \mathrm{ml}(-) ; 60 \mu \mathrm{g} / \mathrm{ml}(*-*) ; 120 \mu \mathrm{g} / \mathrm{ml}(\boldsymbol{\nabla}-\mathbf{v})$

\section{UISCUSSION}

The reaction mechanism proposed for the formation of tenase is

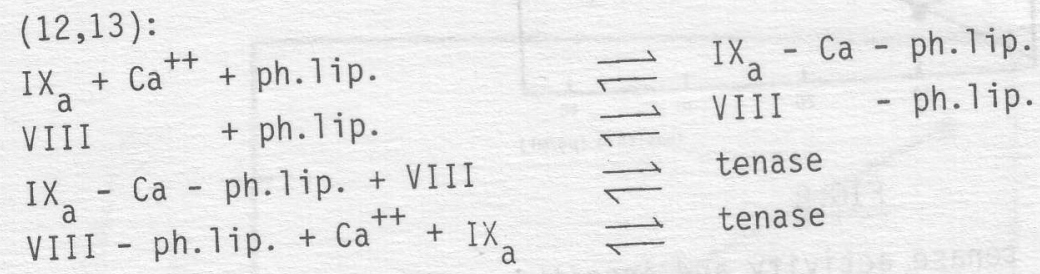

In these equations phospholipid stands for a binding site at the surface of a phospholipid micelle. Tenase is thought to be generated when factor $I_{a}$ and VIII bind next to each other at adjacent binding sites. The binding of factor $I X_{a}$ is by means of a $\mathrm{Ca}^{++}$ion. The binding of factor VIII is presumably hydrophobic. It was our aim to see whether the kinetics of the formation of tenase is compatible wi this reaction scheme.

First we verified whether the reactants participated directly in the formation of tenase and if the tenase activity measured could be used to quantitate the amount of tenase formed. These experiments yielded the following results: 
a. The coagulation factors were functional in the form in which they were added. The tenase forming potency of factor IX $\mathrm{A}_{\mathrm{a}}$ was not enhanced by preincubation with contact product, known to convert factor IX into factor IX $(22)$. Nor was the potency of our preparation of factor VIII enhanced by incubation with thrombin (Table II) (23-25).

b. Under our conditions tenase activity is linear proportional to tenase concentration (figs. 2 and 3 ).

c. The substrate was present in excess since the $K_{m}$ was $0.11 \mathrm{U} / \mathrm{ml}$ and the concentration employed was $0.65 \mathrm{U} / \mathrm{ml}$ (fig. 4). We did not find that factor $\mathrm{IX}_{\mathrm{a}}$ or factor $\mathrm{X}_{\mathrm{a}}$ enhanced the activity of factor VIII as was reported by others $(26,27)$ (Table II).

The following pieces of evidence can be brought forward in favour of the validity of the reaction scheme proposed:

1. All four reactants are necessary for optimal tenase activity. This might alternatively be explained by the action of one of the factors to convert the other into an active tenase $(24,27)$. This is unlikely, however, as a small amount of tenase was generated rapidly upon incubation with a small amount of one factor and a large amount of the other. When one factor enzymatically converted the other into an active tenase one would have expected slow generation of large amounts of tenase. Furthermore, preincubation of the factors VIII and IX did not result in an enhanced formation of tenase (Table III).

2. When factor VIII and factor IX are allowed to bind phospholipid separately before they are incubated together, the tenase generates more slowly and is less active than when the proteins are allowed to bind to the same phospholipid micelle (fig. 5). The tenase that develops can be ascribed to the redistribution of the factors over the micelles. On basis of other experiments others reached the same conclusion for the prothrombin complex (5) as well as for the tenase complex (11).

3. The reaction mechanism proposed for tenase formation is completely analogous to the formation of prothrombinase from the factors $V$, $X_{a}$, phospholipid and $\mathrm{Ca}^{++}(12)$. The same type of reaction kinetics will therefore hold and the dependence of tenase concentration upon the concentration of factors VIII, IX $x_{a}$ and phospholipid will be: 


$$
1 / c=p / k\left(1 / n+1 / p+k^{\prime} / n \cdot p\right)(1 / e+1 / p)\left(1 / e+1 / p+k^{\prime \prime} / e \cdot p\right)
$$

where $c=$ concentration of tenase, $p=$ concentration of phospholipid, $n=$ concentration of factor $I_{a}$, e=concentration of factor VIII, $k, k^{\prime}$ and $k^{\prime \prime}$ are constants.

When the concentration of factor IX or factor VIII is varied and all other concentrations are kept constant, the formula predicts a linear relatior ship between $1 / \mathrm{c}$ and the inverse of the factor concentration. Figs. 6 and 7 do not refute this prediction.

When the relationship between $c$ and $p$ is to be examined, the formula is best written in the form:

$$
1 / c=(p+1 / p)\left(n+k^{\prime}\right)\left(e+k^{\prime \prime}\right)+\left(n+e+k^{\prime}+k^{\prime \prime}\right) 1 / n \cdot e \cdot k \text {. }
$$

At small concentrations of $p$ the first term will become neglegible compared to the second one so that a linear relationship between $1 / \mathrm{c}$ and $1 / p$ is found. At high concentrations of $p$ the second term will become neglegible and $1 / c$ will be a linear function of $p$. The observed relations are compatible with the prediction from the proposed model (fig. 8 ).

Also compatible with the proposed model is that after dilution of a concentrated tenase preparation the activity initially is a proportional fraction of the original activity but next declines to a lower level. This may be due to dissociation of the tenase complex (figs. 2 and 3 ).

Not immediately apparent from the proposed reaction mechanism is the fact that at inhibitory phospholipid concentrations the tenase activity forms more slowly. The proposed mechanism explains inhibition by high concentrations of phospholipid by the fact that at a large phospholipidwater interphase the chance for a molecule of factor VIII to adsorb next to a molecule of factor IX is small. In formula $2 p$ will dominate over $1 / p$ and $1 / \mathrm{c}$ will grow, i.e. $\mathrm{c}$ will decrease. No interactions between the two proteins are postulated. It is known that proteins at a lipid-water interphase can have a lateral mobility (28-31). So the two factors can attain a favourable juxtaposition after having been adsorbed. When we postulate a (weak) interaction between the factor VIII and IX ${ }_{a}$, the complex will, ance formed, not readily drift apart. This mechanism could explain the slow format of tenase activity. The enzyme substrate complex is a ternary complex of the factors IX ${ }_{a}$, VIII, and $X$. The protein-protein interaction in the enzymesubstrate complex may be higher than that in the tenase complex. This would explain the enhanced formation of tenase activity after addition of the substrate (fig. 5). 
We conclude that the kinetics of the formation of tenase activity from purified coagulation factors do not refute the model that predicts the activity as arising from factor $I_{\mathrm{A}}$ and factor VIII adsorbed next to each other at a phospholipid-water interphase.

The kinetic effects studied here are difficult to compare to those from Fujikawa et a1.(23) as the latter have been obtained at a phospholipid concentration of $\sim 70 \mu \mathrm{g} / \mathrm{ml}$ which is in the inhibitory range (fig. 8) and hence will show the anomalous features discussed above.

\section{ACKNOWLEDGEMENTS}

We thank Dr.J.v.Mourik (Central Laboratory of the Red Cross Blood Transfusion Service, Amsterdam) for kindly providing the purified factor VIII and Drs.M.J. Lindhout (State University Limburg, Maastricht) for a generous gift of purified factor $X$.

The Dutch-Hungary Scientific Exchange Program has provided the financial support for a four month's stay of Dr.Varadi in Holland.

The investigations were carried out under the auspices of a project of the Organization for Health Research TNO (The Hague).

\section{REFERENCES}

2. ESMON,C.T., JACKSON,C.M. The conversion of prothrombin to thrombin. III. The factor $x_{a}$ catalyzed activation of prothrombin. J.Biol.Chem. 249, 7782,1974a.

2. ESMCH,C.T.,JACKSON,C.M. The conversion of prothrombin to thrombin. IV. The function of the fragment 2 region during activation in the presence of factor V. J.Biol.Chem. 249, 7791, 1974b.

3. BARTON,P.G., JACKSON, C.M.,HANAHAN,D.J. Relationship between factor $V$ and activated factor $X$ in the generation of prothrombinase. Nature 214,923,1967.

4. JOBIN, F., ESNOUF,M.P. Studies on the formation of the prothrombin converting complex. Bioch.J. 102, 666, 1967.

5. COLE,E.R., KOPPEL,J.L., OLWIN,J.H. Autoprothrombin C from a commercial thrombin product. Thrombos. Diathes. haemorrh. 14, 431,1965.

6. ESNOUF,M.P., JOBIN,F. Lipids in prothrombin conversion. Thrombos. Diathes. haemorrh. Supp1.17, 103 (1965).

7. HANAHAN,D.J., PAPAHADJOPOULOS,D. Interaction of phospholipids with coagulation factors. Thrombos. Diathes. haemorrh. Supp1. 17, 71 (1965).

8. PAPAHADJOPOULOS, D. ,HANAHAN,D.J. Observations on the interaction of phospholipids and certain clotting factors in prothrombin activator. Bioch. Bioph. Acta $20,436,1964$.

9. HEMKER, H.C., ESNOUF, M.P. ,HEMKER, P.W. , SWART, A.C.W. MACFARLANE, R.G. Kinetics of the formation of prothrombin converting activity in a purified system. Nature 215, 248, 1967. 